\title{
PRIVATE ACCREDITATION AS A SUBSTITUTE FOR DIRECT GOVERNMENT REGULATION IN PUBLIC HEALTH INSURANCE PROGRAMS: WHEN IS IT APPROPRIATE?
}

\author{
ELEANOR D. KINNEY*
}

I

\section{INTRODUCTION}

Private accreditation of health care institutions serves crucial quality assurance functions in the American health care system. Since the advent of widespread third-party payment for health care services in the mid-twentieth century, third-party payers have used private accreditation to thereby identify which health care institutions are qualified to provide services for payment to their beneficiaries. Private accreditation serves to alleviate the need for thirdparty payers to make independent assessments of the quality of their providers' facilities and services.

As the federal government and states became third-party payers when the Medicare and Medicaid programs came on-line in 1965, they used private accreditation to identify qualified hospitals in a fashion similar to that of private insurers. For hospitals and, later, other health care institutions, the federal government and states used private accreditation as evidence of compliance with Medicare conditions of participation and state licensure laws, respectively. In so doing, the government effectively delegated regulatory responsibility for assuring that health care institutions meet the requisite quality standards for participation in their respective programs.

When government relies on private accreditors to perform this important function, questions arise as to whether all the legitimate interests of the public served by public health insurance programs are adequately protected and/or promoted. First, are private accreditors capable of identifying the characteristics of health care institutions and the services they provide that assure quality of care and of developing uniform standards? Second, do private accreditors have sufficient staff and resources to ensure compliance with quality standards?

\footnotetext{
Copyright $(\mathcal{O} 1995$ by Law and Contemporary Problems

* Professor of Law and Director of The Center for Law and Health, Indiana University School of Law-Indianapolis.

I would like to thank the following research staff for their tremendous efforts on this article: Kurt Snyder, Brian Smith, Susan Bizzell, Robyn Crawford, Phillis Bonds, and Marcia Gonzales.
} 
Third, does government selection of one private accrediting body give an inappropriate imprimatur to one organization vis-à-vis another competing accrediting organization? Finally, does such government selection inappropriately shape the direction of quality assurance standards for affected health care institutions as well as distort the information about quality that consumers might derive from the fact of accreditation, particularly information from competing but unannointed accreditors?

These issues are especially important in today's health care reform climate because health care institutions are fundamentally changing the types of care they deliver and the ways in which they deliver it. More and more, acute and long-term care is provided on an outpatient basis or at home. At the same time, new types of health care institutions are emerging. Also, new ways of defining and measuring quality of health and long-term care services are emerging that are revolutionizing quality assurance methods for health care services. The Clinton Administration, Congress, and many states considered various proposals for a comprehensive public health insurance program. ${ }^{1}$ These proposals have extensive provisions for quality assurance and monitoring. ${ }^{2}$ Yet little attention was given to the role that private accreditation should play in the regulation of health care institutions under any of these reform proposals.

This article explores the appropriateness of the use of private accreditation in defining and regulating the quality of health care providers under government health insurance programs. First, the article describes the various functions of private accreditation in public health insurance programs. Second, it reviews the history of the use of private accreditation in state licensure programs as well as in the Medicare and Medicaid programs. Third, it proposes a theory for deciding when private accreditation should be used by public health insurance programs for defining and regulating the quality of different types of health care institutions. The article concludes with some general observations about how the role of private accreditation could be structured to protect and promote all legitimate interests of consumers and providers in the quality of their various health care institutions.

1. See, e.g., Comprehensive Family Health Access and Savings Act, S. 1796, 103d Cong., 1st Sess. (1993); Health Equity and Access Reform Today Act of 1993, S. 1770, 103d Cong., 1st Sess. (1993); Consumer Choice Health Security Act of 1993, S. 1743, 103d Cong., 1st Sess. (1993); The Health Security Act of 1993, H.R. 3600, 103d Cong., 1st Sess. (1993) (The President's Proposal); The Managed Competition Act of 1993, H.R. 3222, 103d Cong., 1st Sess. (1993); Affordable Health Care Now Act of 1993, H.R. 3080, 103d Cong., 1st Sess. (1993); The Mediplan Act of 1993, H.R. 2610, 103d Cong., 1st Sess. (1993); The American Health Security Act of 1993, H.R. 1200, 103d Cong., 1st Sess. (1993); see also Deborah L. Rogal \& W. David Helms, State Models: An Overview, HeALTH AFFAIRS, Summer 1993 , at 27.

2. Timothy S. Jost, Health System Reform: Forward or Backward with Quality Oversight?, 271 JAMA 1508 (1994). 
II

\section{The Tradition of Private Accreditation}

\section{A. The Functions of Accreditation}

The basic purpose of accreditation is to establish that an organization has met and continues to meet specified standards. Accreditation serves as an assurance of quality for consumers of the organization's services. It is a voluntary process by which an organization demonstrates that it meets the standards established by professional peers. Organizations seeking accreditation are generally nonprofit entities that offer valued services-health care or education, for example - about which consumers have difficulty assessing quality without expert guidance. Customarily, accreditation is performed by private organizations that have expertise in defining and measuring the quality of services offered by the organization seeking accreditation.

Accreditation involves two important and distinct functions. First, it defines standards by which to establish and measure quality. Second, it determines whether organizations have complied with these standards, thereby warranting accreditation. In administrative law parlance, the standard-setting function is a legislative function in that it involves prospective policymaking of general applicability, and the compliance determination is an adjudicative function of ascertaining whether a particular organization is actually in compliance with established standards. ${ }^{3}$

Congress and administrative agencies have often delegated their respective legislative functions to private organizations, and they have adopted the standards of these organizations for public regulatory programs. ${ }^{4}$ The rationale for such delegation is that private bodies have unique expertise, leading to better standards. ${ }^{5}$ It is less common for Congress and administrative agencies to delegate a compliance determination function, although private accreditors also have staffs with expertise to determine if standards are in fact being met. ${ }^{6}$

This distinction between the legislative function of establishing standards and the adjudicative function of compliance determination is crucial in the health care field for another reason. The compliance determination function goes to the heart of whether a specific provider of services has the requisite resources,

3. Bernard Schwartz, Administrative Terminology and the Administrative Procedure Act, $48 \mathrm{MICH}$. L. REV. 57 (1949).

4. See, e.g., Harold I. Abramson, A Fifth Branch of Government: The Private Regulators and Their Constitutionality, 16 HASTINGS CONST. L.Q. 165 (1989); Kurt L. Hanslowe, Regulation by Visible Public and Invisible Private Government, 40 TEX. L. REV. 88 (1961); Louis L. Jaffe, Law Making by Private Groups, 51 HARV. L. REV. 201 (1937); Harold J. Krent, Fragmenting the Unitary Executive: Congressional Delegations of Administrative Authority Outside the Federal Government, 85 Nw. U. L. REV. 62 (1990); Note, Delegation of Governmental Power to Private Groups, 32 COLUM. L. REV. 80 (1932).

5. See Abramson, supra note 4, at 179-80; Krent, supra note 4, at 85-86.

6. Abramson, supra note 4, at 194-99; Hanslowe, supra note 4, at 113-27. 
management, and experience to protect public health and safety in the delivery of services. To what extent should government turn such a crucial responsibility over to private organizations and, if it does so, how can it be sure that the function is being performed in a manner that ensures protection of the public and also fairness to providers?

\section{B. Licensure and Private Accreditation in the Health Care Industry}

Government has historically assumed a minimal role in regulating the quality of care provided in health care institutions. Indeed, government regulation of health care institutions in any capacity is a very recent phenomenon. ${ }^{7}$ Until the twentieth century, most health care was provided at home. Only the poor received care in health care facilities, often as a last resort and on a charity basis. ${ }^{8}$ Their lack of direct governmental regulation is attributable to the unique historical development of health care institutions in the United States.

Historically, hospitals were institutions like almshouses that took care of the destitute. ${ }^{9}$ In the late nineteenth century, hospitals began to assume a different role and function in the U.S. health care system. ${ }^{10}$ As medical science progressed, the medical profession developed the hospital as the institution in which it could best provide highly technical care. Hospitals then became citadels of healing under the dominance of the medical profession, as they remain today. ${ }^{11}$

The history of nursing homes is much different. Unlike hospitals, nursing homes as distinct organizations emerged during the Great Depression when homeowners sought to augment their incomes and often protect ownership of their homes by taking in aged individuals for money. ${ }^{12}$ Gradually, two crucial trends developed: boarding homes hired nurses and styled themselves as "nursing" homes to attract more clients, and absentee owners replaced resident

7. See Michael G. Macdonald et al., Health Care law: A Practical Guide \$ 5.02 (1985); KenNeth R. WING, The LAW AND THE Public's HeAlth 120 (2d ed. 1985); Louise Lander, Licensing of Health Care Facilities, in LEGAL ASPECTS OF HEALTH POLICY: ISSUES AND TRENDS 128 (Ruth Roemer \& George McKray eds., 1980); Milton I. Roemer, Controlling and Promoting Quality in Medical Care, 35 LAw \& CONTEMP. PRoBs. 284 (Spring 1970); William Worthington \& Laurens H. Silver, Regulation of Quality of Care in Hospitals: The Need for Change, 35 LAW \& CONTEMP. PROBS. 305 (Spring 1970).

8. See Paul Starr, The Social Transformation of American Medicine 145-54 (1982).

9. See id. at 147; John H. Knowles, Emergence of the Hospital as a Social Institution, in MAINSTREAMS OF MEDICINE: ESSAYS ON THE SOCIAL AND INTELlECTUAL CONTEXT OF MEDICAL PRACTICE 53-73 (Lester S. King ed., 1971).

10. George Rosen, The Hospital: Historical Sociology of a Community Institution, in THE Hospital IN MODERN Society (Eliot Freidson ed., 1963); Charles E. Rosenberg, Inward Vision and Outward Glance: The Shaping of the American Hospital, 1880-1914, in SOCIAL HISTORY AND SOCIAL POLICY (David J. Rothman \& Stanton Wheeler eds., 1981).

11. See STARR, supra note 8, at 145-179; see also DAVID ROSNER, A ONCE CHARITABLE ENTERPRISE: HOSPITALS AND HEALTH CARE IN BROOKLYN AND NEW YORK, 1885-1915 (1982).

12. Michael R. Carlston, Government Regulation of Nursing Homes-An Inquiry, 1973 UTAH L. REV. 270; Lander, supra note 7, at 132; John J. Regan, Quality Assurance Systems in Nursing Homes, 53 J. URB. 153 (1975). 
owners. ${ }^{13}$ The development of nursing homes was enhanced by enactment of the Old Age Assistance program in 1935, which paid for limited nursing home care and allowed states to move elderly poor to nursing homes from state or locally funded almshouses. ${ }^{14}$ The modern nursing home industry really took shape following enactment of the Medicare and Medicaid programs in 1965, both of which included nursing home benefits. The number of nursing homes, particularly for-profit facilities, increased 140 percent between 1960 and 1976, and nursing home beds increased more than three hundred percent during the same period. ${ }^{15}$

The unique history of nursing homes as nonmedical, for-profit ventures is important to the subsequent history of the safety and quality problems with nursing home care and the regulation of nursing homes. Indeed, the history of nursing homes has been replete with serious concerns about service quality and even safety of residents. ${ }^{16}$

Home health agencies have quite a different history from both hospitals and nursing homes. The initial impetus for the development of home health agencies was the visiting nurse movement of the late nineteenth century. ${ }^{17}$ The public health nursing and visiting nurse agencies of today emerged from the Sanitary Revolution and other reform movements of the nineteenth century. ${ }^{18}$ Like nursing homes, Medicare and Medicaid had a dramatic impact on the growth and shape of the home health industry. Between 1967 and 1985, the number of Medicare certified home health agencies, a great number of which were for-profit, increased from 1809 to $5983 .{ }^{19}$ Much of the expansion occurred after 1980, when Congress eliminated several Medicare program requirements such as the prior hospitalization requirement, the cap on covered days, and many restrictions on the participation of for-profit agencies. ${ }^{20}$

The historical development of quality assurance for health care institutions is characterized by two important and interrelated trends: private accreditation and state licensure. The earliest formal efforts for quality assurance in health care institutions developed in hospitals. A crucial development occurred in 1919, when the American College of Surgeons established the Hospital

13. Lander, supra note 7 , at 132 ; Regan, supra note 12 , at 156.

14. Social Security Act of 1935, Pub. L. No. 74-271, §§ 1-2, 49 Stat. 620 (codified at scattered sections of 42 U.S.C.); see Lander, supra note 7, at 132.

15. Frank E. Moss \& Val J. Halamandaris, Too Old, Too Sick, Too Bad 6-7, Figure 1.1 (1977).

16. MARY A. MENDELSON, TENDER Loving GReEd (1974); Moss \& HALAMANDARIS, supra note 15; Bruce C. Vladeck, Unloving CARE: THe Nursing Home Tragedy (1980).

17. Josephine A. Dolan, History of NURSING 260 (1968).

18. Philip A. Kalisch \& Beatrice J. Kalisch, The Advance of American Nursing 410 (1986).

19. Robert G. Hoyer, Recent Medicare Cutbacks: Their Impact on Home Health Agency Participation, CARING (Aug. 1988) 58, 59 (citing unpublished Health Care Financing Administration data).

20. Omnibus Reconciliation Act of 1980, Pub. L. No. 96-499, 8 930, 94 Stat. 2599, 2631-33 (codified as amended in scattered subsections of 42 U.S.C. $\S 1395$ (1988 \& Supp. V 1993)); see SHELAH G. LEADER, HOME HEALTH BENEFITS UNDER MEDICARE (1986). 
Standardization Program, thus adopting and promoting a private accreditation model. ${ }^{21}$ Throughout the early twentieth century, hospital quality assurance remained predominantly a private matter.

State licensure, the major regulatory tool for assuring that health care institutions meet minimal quality standards, followed private accreditation. Most states did not require licensure of hospitals and other health care institutions until the middle of the twentieth century. The Hill-Burton Act, enacted in 1946, required state licensure as a condition for receiving construction funds and other financial assistance, and the program suspended funding to states that did not have the requisite licensure requirements for hospitals and other health care institutions. ${ }^{22}$

In the early 1950s, the American College of Surgeons joined with other physician professional associations and the American Hospital Association to establish the Joint Commission on Accreditation of Hospitals (the "JCAH"). ${ }^{23}$ In part, this move was inspired by the states, which had been licensing hospitals to comply with the Hill-Burton Act. Hospitals and the medical profession were concerned about maintaining private accreditation as the predominant regulatory model as it accorded the hospital industry autonomy and control over the definition and regulation of quality in hospitals. ${ }^{24}$

Since the 1950s, the JCAH, now the Joint Commission on Accreditation of Healthcare Organizations (the "JCAHO"), ${ }^{25}$ has been the predominant private accrediting body for allopathic health care organizations. Initially, the JCAHO accredited only hospitals. However, it added a program for psychiatric facilities in 1960 and a program for rehabilitation facilities in $1967 .^{26}$ It is noteworthy that the movement for developing private standards through accreditation, like licensure, was spurred by the Hill-Burton hospital construction program. ${ }^{27}$ Further, states used JCAHO accreditation increasingly in their own licensure programs to set licensure standards and demonstrate compliance with those standards. $^{28}$ By 1983, thirty-seven states had incorporated JCAHO accreditation in some capacity. ${ }^{29}$

21. Timothy S. Jost, The Joint Commission on Accreditation of Hospitals: Private Regulation of Health Care and the Public Interest, 24 B.C. L. REV. 835, 841-49 (1983); Carl P. Schlicke, American Surgery's Noblest Experiment, 106 ARCHIVES OF SURGERY 379 (1973).

22. Hospital Survey and Construction Act, Pub. L. No. 79-725, 60 Stat. 1040 (1946) (codified as amended at 42 U.S.C. $\$ \S 291 \mathrm{a}-2910$ (1988)); see MACDONALD ET AL., supra note 7, at $\$ 5.02$; WING, supra note 7, at 120 ; Jost, supra note 21 , at $849-50$.

23. See Jost, supra note 21, at 849-52; James S. Roberts, et al., A History of the Joint Commission on Accreditation of Hospitals, 258 JAMA 936 (1987).

24. Jost, supra note 21 , at 854 .

25. In 1987, the JCAH changed its name to the JCAHO in response to the increasingly diverse nature of modern health care institutions. JOINT COMM'N ON ACCREDITATION OF HEALTHCARE ORGS., COMMITTED TO QUALITY: AN INTRODUCTION TO THE JOINT COMMISSION ON ACCREDITATION OF HEALTHCARE ORGANIZATIONS 14 (1990).

26. Jost, supra note 21 , at 852 .

27. Roemer, supra note 7, at 284.

28. Jost, supra note 21 , at 844 n.65.

29. Id. 
The availability of funds for nursing home care under the Old Age Assistance program of the Social Security Act of $1935^{30}$ encouraged thirty-five states to initiate licensure for nursing homes. ${ }^{31}$ The remaining states adopted licensure for nursing homes by mid-century in response to the 1950 amendments to the Old Age Assistance nursing home benefit ${ }^{32}$ that allowed payments directly to licensed providers on the condition that states establish and enforce standards for funded institutions. ${ }^{33}$ In 1953, Congress extended the Hill-Burton Act construction benefits to nonprofit long-term care facilities and imposed the same condition of state licensure for receipt of federal funding. ${ }^{34}$ These additional mandates finally moved all states to begin licensing nursing homes. ${ }^{35}$

Within a few years of its creation, the JCAHO developed accreditation standards for long-term care facilities. In 1965, the JCAHO expanded its scope to include accreditation of long-term care organizations and included representatives of nursing home trade associations as JCAHO commissioners. ${ }^{36}$ However, by refusing to incorporate JCAHO accreditation of nursing homes into the Medicare quality assurance system in the way it did for hospitals, ${ }^{37}$ the federal government reduced incentives for JCAHO's efforts to enlist long-term care facilities to pursue JCAHO accreditation. ${ }^{38}$

In contrast, states were quite late in getting into the business of licensing home health agencies. Indeed, it was not until after the enactment in 1965 of the Medicare and Medicaid programs, which included home health as a covered benefit, that most states adopted their home health agency licensure statutes. ${ }^{39}$ The Medicare program required participating home health agencies to comply with Home Health Agency Conditions of Participation, and the Medicaid program required home health agencies to be licensed under state law. ${ }^{40}$ Interestingly, contemporary observers of the early years of the Medicare program assert that the Medicare Conditions of Participation for home health agencies were the first standards for home health agencies ever developed. ${ }^{41}$

30. See supra note 14 and accompanying text.

31. See Patricia A. Butler, Assuring the Quality of Care and Life in Nursing Homes: The Dilemma of Enforcement, 57 N.C. L. REV. 1317, 1319 (1979).

32. Social Security Amendments of 1950, Pub. L. No. 81-734, $§ 303,64$ Stat. 477, 549 (codified as amended at 42 U.S.C. $\S 306(1988)$ ).

33. See Butler, supra note 31, at 1319.

34. Medical Facilities Survey and Construction Act of 1954, Pub. L. No. 68-482, \& 4(g), 68 Stat. 461, 465 (codified at 42 U.S.C. $\$ 632$ ) (repealed Oct. 13, 1988).

35. Lander, supra note 7 , at 132-33.

36. Jost, supra note 21 , at 852 . In a subsequent reorganization, the JCAHO eliminated the longterm care representatives from the Commission. Id.

37. See infra notes $69-70$ and accompanying text.

38. See Schlicke, supra note 21.

39. Sandra H. Johnson, Quality-Control Regulation of Home Health Care, 26 HoUS. L. REv. 901, 935 (1989).

40. Social Security Amendments of 1965, Pub. L. No. 89-97, $\$ \S 1861$ (o), 1902(a)(22)(B), 79 Stat. $286,319,348$ (codified as amended at 42 U.S.C. $\$ \S 1395 \times(0), 1396 a(a)(22)(B)(1988)$ ); see Paul E. Hankwitz, Quality Assurance in Home Care, 7 GeRIATRIC HOME CARE 847, 852-53 (1991).

41. HeRman M. SOMERS \& ANNe R. SOMERS, MEdicare AND the Hospitals: IsSues and PROSPECTS 36 (1967). 
Currently, about forty states actually license home health agencies and require them to meet quality standards as a condition of licensure. ${ }^{42}$ However, most states require licensure only if the home health agency provides skilled nursing services. ${ }^{43}$ In general, state licensure of home health agencies tends to be undeveloped and narrow in coverage with inconsistent or even lax enforcement. ${ }^{44}$

Perhaps one reason that home health agencies are treated differently with respect to state licensure than are hospitals or nursing homes is the tradition of pluralistic accreditation of home health agencies through organizations of the nursing profession. The National League of Nursing has accredited home health agencies for nearly thirty years, ${ }^{45}$ with a total of about six hundred agencies presently accredited. ${ }^{46}$ The JCAHO got involved with home health agency accreditation late in the game. It did not begin accrediting hospital-based home health agencies until the late $1970 \mathrm{~s} .{ }^{47}$ The JCAHO currently accredits more than 3000 home care organizations, of which 1700 are also Medicare certified agencies. ${ }^{48}$ In 1988, the JCAHO issued its first standards for free-standing home health agencies, and since then it has become increasingly involved in quality issues in home-based, long-term care. ${ }^{49}$ Despite the pluralistic tradition, private accreditation has never had much currency or support among home health professionals as it has had with the hospital community. ${ }^{50}$

In sum, the licensure and private accreditation efforts for health care facilities occurred contemporaneously. Further, both efforts were spurred on by government programs to fund facility construction or services. Consequently, when states got into the business of regulating health care institutions, they relied heavily on the mechanism of private accreditation as a means of determining whether health care institutions met the requisite standards for licensure. ${ }^{51}$ Indeed, as indicated above, nearly two-thirds of states have

42. Johnson, supra note 38 , at $933-34$ (desribing and analyzing in detail state licensure of home health agencies).

43. Id.

44. Id. at 923.

45. National league for Nursing, accreditation of home Health Agencies and COMMUNITY NURSING SERVICES (1976), as updated, NAT'L LEAGUE FOR NURSING, ACCREDITATION CRITERIA, STANDARDS, AND SUBSTANTIATING EVIDENCES (1987); see Johnson, supra note 38, at 906. 46. Telephone interview with Harry Wade, Director of Public Information Services, National League of Nursing (Jan. 11, 1994).

47. JoINT COMm'N ON THE ACCREditation OF HOSPS., ACCRedtTation MANuAl for HOSPITALS 47 (1978), as updated, JOINT COMM'N ON THE ACCREDITATION OF HEALTHCARE ORGS. (JCAHO), STANDARDS FOR THE ACCREDITATION OF HOSPITALS (1993); see Johnson, supra note 38, at 905 n. 20 .

48. Deemed Status Option Now Available for Joint Commission Accredited Home Health Agencies, JOINT COMMISSION BULLETIN: HOME CARE: AN UPDATE ON THE JOINT COMMISSION'S ACCREditation Program (JCAHO/Dept. of Publications, Chicago, Ill.), Summer 1993 at 1, 2.

49. See, e.g., JoINT COMM'N ON ACCREDITATION OF HEALTHCARE ORGS., QUALITY IMPROVEMENT IN HOME CARE (1993); JOINT COMM'N ON ACCREDITATION OF HEALTHCARE ORGS., QUALITY assurance in Home Care Organizations and Hospice Programs (1990).

50. Johnson, supra note 38 , at 931.

51. Jost, supra note 21 , at $844-45$. 
incorporated JCAHO standards into licensing programs for health care institutions. $^{52}$ In so doing, many states also left the determination of licensure standards to private accrediting bodies, a situation which remains true today. ${ }^{53}$

III

\section{The Use of Private ACCREditation in the Medicare and Medicaid PROGRAMS}

Utilizing private health insurance to pay for health care services provided in institutions became widespread in the middle of the twentieth century. ${ }^{54}$ Health insurers used private accreditation to perform two critical functions: (1) assuring that covered services for which they paid were provided by a high quality provider, defined as an accredited provider, and (2) defining covered benefits as only services furnished by an accredited provider. Indeed, about twenty percent of private health insurance plans of Blue Cross and Blue Shield-the predominant health insurer in the mid-twentieth century-used private accreditation to accomplish one or both of these functions. ${ }^{55}$

\section{A. The Medicare Program}

Consequently, it is not surprising that Congress looked to private accreditation as a quality assurance mechanism for the Medicare program. ${ }^{56}$ The Johnson Administration and Congress were both anxious to get Medicare up and running as quickly as possible but were concerned that the program pay only for high quality care. ${ }^{57}$ Further, the federal government needed the cooperation of hospitals and physicians to launch the program successfully. The use of private accreditation was reassuring to hospitals and the medical profession, and it was instrumental in securing their eventual cooperation in the Medicare program. ${ }^{58}$

The Department of Health, Education, and Welfare ("HEW") also viewed private accreditation in the Medicare program as a mechanism for assuring that the Medicare program did not intrude inappropriately into the practice of medicine or hospital management. ${ }^{59}$ Further, Congress explicitly did not want

52. See supra note 29 and accompanying text.

53. MACDONALD ET AL., supra note 7, at $\$ 5.02$; Worthington \& Silver, supra note 7, at 305.

54. See Herman M. Somers \& Anne R. Somers, Private Health Insurance, Part One: Changing Patterns of Medical Care Demand and Supply in Relation to Health Insurance, 46 CAL. L. REV: 376 (1958); Herman M. Somers \& Anne R. Somers, Private Health Insurance, Part Two: Problems, Pressures and Prospects, 46 CAL. L. REV. 508 (1958).

55. Schlicke, supra note 21 , at 381 .

56. Social Security Amendments of 1965 , Pub. L. No. $89-97, \S 1861$ (e), 79 Stat. 286,314 (codified as amended at 42 U.S.C. $\$ 1395 \times(e)(1988$ \& Supp. V 1993)).

57. See Jost, supra note 21, at 853; see also JUDITH M. FEDER, MEDICARE: THE POLITICS OF FEDERAL HOSPITAL INSURANCE 7-32 (1977) (discussing in detail the deliberations over the role of the JCAH in the Medicare program).

58. SOMERS \& SOMERS, supra note 40 , at 87 ; Jost, supra note 21 , at 853 .

59. FEDER, supra note 56 , at 7-10 \& n.4. 
to supplant the hospital industry's extant quality assurance activities, ${ }^{60}$ stating in committee reports that "[ $\mathrm{t}]$ he inclusion of these conditions is designed to support the efforts of the various professional accrediting organizations sponsored by their medical and hospital associations, health insurance plans, and other interested parties to improve quality of care in hospitals."61

As a mechanism of further defining covered benefits, Congress established statutory definitions of health care institutions that were eligible to participate in the Medicare program. ${ }^{62}$ Congress also required the Secretary of HEW to develop conditions of participation for health care institutions to define the quality and other standards to be met by providers participating in the Medicare program. $^{63}$ The Secretary subsequently developed conditions of participation for hospitals, nursing homes, home health agencies, and other health care institutions. $^{64}$

Congress initially adopted some interesting provisions regarding the conditions of participation as well as the role of private accreditation in determining compliance with these conditions. Specifically, the Medicare statute originally provided that "requirements [in the conditions of participation] could not be higher than the comparable requirements prescribed for the accreditation of hospitals by the JCAH." provision to ensure the dominance of private regulation of hospitals through the JCAHO. ${ }^{66}$ Nevertheless, states could still technically preclude accredited hospitals from participating in Medicare, as the Medicare statute required hospitals to comply with state licensure laws where present. ${ }^{67}$

Also, in the Social Security Amendments of 1965, Congress established that private accreditation by the JCAHO would constitute a conclusive determination of quality for purposes of the Medicare program. The statute authorized similar treatment of private accreditation of hospitals, nursing homes, and home health agencies by the American Osteopathic Association or "any other national accreditation body" if the Secretary finds that the accrediting body provides "reasonable assurance that any or all conditions" of the definitive requirements for hospitals, extended care facilities, and home health agencies in section $1861^{68}$ are met. ${ }^{69}$ Initially, HEW made the "deeming" mechanism available

60. Id. at 7 .

61. S. REP. No. 404. 89th Cong., 1st Sess. $28-29$ (1965), reprinted in 1965 U.S.C.C.A.N. 1943, 1969; H.R. REP. No. 213, 89th Cong. 1st Sess. 25-26 (1965), reprinted in 1965 U.S.C.C.A.N. 1943, 1969.

62. Social Security Amendments of 1965 , Pub. L. No. 89-97, $\$ \$ 1861(\mathrm{e}),(\mathrm{j}),(\mathrm{o}), 79$ Stat. 286, 314-15, $317-18,320-21$ (codified as amended at 42 U.S.C. $\$ \S 1395 \times(e),(j),(0)(1988 \&$ Supp. V 1993)).

63. Id.

64. See 42 C.F.R. $\$ \S 482.1-.66$ (1993) (hospitals); id. $\S \S 483.1-.480$ (nursing homes); id. $\$ \S 484.1-.52$ (home health agencies).

65. Social Security Amendments of 1965, Pub. L. No. 89-97, $\S 1861($ e)(8), 79 Stat. 286,314 (codified as amended at 42 U.S.C. $\$ 1395(e)(8)(1988)$ ).

66. See FEDER, supra note 56, at 7-10.

67. Social Security Amendments of 1965 , Pub. L. No. 89-97, \& 1861(e)(7), 79 Stat. 286, 314 (codified as amended at 42 U.S.C. $\$ 1395 \times(e)(7)(1988)$ ); Jost, supra note 21 , at 853 \& n.163.

68. Social Security Amendments of 1965 , Pub. L. No. 89-97, $\S 1865,79$ Stat. 286,326 (codified as amended at 42 U.S.C. $\$ 1395 b b$ (1988 \& Supp. V 1993)); Jost, supra note 21, at 853 \& n.163. 
only to hospitals. ${ }^{70}$ Only recently, the Department of Health and Human Services ("HHS") extended the "deeming" mechanism to all healthcare institutions including nursing homes."

Pursuant to the "deeming" mechanism, the Medicare program could recognize accreditation of a health care institution by a private accrediting body as compliance with Medicare Conditions of Participation. ${ }^{72}$ Initially, private accreditation insulated accredited health institutions from routine inspections by state survey agencies to determine compliance with federal requirements, and accreditation reports were confidential even with respect to HEW and state regulators. ${ }^{73}$ Despite use of the "deeming" mechanism, health care institutions have been subject to validation and complaint investigation surveys since shortly after inauguration of the Medicare program.

In the Social Security Amendments of 1965 , Congress also explicitly required that psychiatric and tuberculosis hospitals be accredited in order to participate in the Medicare program. ${ }^{74}$ In so doing, Congress used JCAHO accreditation as a means of actually defining the psychiatric and tuberculosis hospital benefits. In Cospito v. Heckler, the U.S. Court of Appeals for the Third Circuit upheld Medicare's use of private accreditation to set standards for health care institutions against a challenge that such standard-setting was an improper delegation. ${ }^{75}$ In 1984, Congress amended the conditions of participation for psychiatric and tuberculosis hospitals to remove this requirement. ${ }^{76}$

\section{B. The Medicaid Program}

Because Medicaid is a joint federal/state program with primary administrative responsibilities lying with the states, Congress provided a different arrangement for assuring the quality of health care institutions participating in the Medicaid program. Specifically, Congress mandated as a state plan requirement that states establish standards for institutions serving Medicaid recipients. ${ }^{77}$ Most states already had licensure programs for hospitals and nursing homes in place, as licensure of hospitals and nursing homes was a requirement for state participation in the Hill-Burton program. ${ }^{78}$ Further, in the late 1960s, HEW

69. Social Security Amendments of 1965, Pub. L.No. 89-97, \& 1865, 79 Stat. 286, 326 (codified as amended at 42 U.S.C. § 1395 bb (1988 \& Supp. V 1993)).

70. Medicare Program: Granting and Withdrawal of Deeming Authority to National Accreditation Organizations, 58 Fed. Reg. 61,816 (1993) (to be codified at 42 C.F.R. pts. 401, 488, 489).

71. Id; see infra notes 86-90,113,115-16 and accompanying text.

72. See supra notes $69-70$ and accompanying text.

73. See Jost, supra note 21 ; at $856-57$.

74. Social Security Amendments of 1965, Pub. L. No. 89-97, $\$ \S 1861(\mathrm{f}),(\mathrm{g}), 79$ Stat. 286, 315-16 (codified as amended at 42 U.S.C. \$\$ $1395 \times(f),(g)(1988)$ ).

75. See, e.g., Cospito v. Heckler, 742 F.2d 72 (3d Cir. 1984), cert. denied, 471 U.S. 1131 (1985).

76. Deficit Reduction Act of 1984, Pub. L. No. 98-369, $\$ \S 2335(b)(1), 2340(a)(1)(4), 98$ Stat. 499, 1091, 1093 (codified as amended at 42 U.S.C. $\$ 1395 x$ (1988 \& Supp. V 1993)).

77. Social Security Amendments of 1965, Pub. L. No. 89-97, \&1902(a)(22)(B), 79 Stat. 344, 348 (codified as amended at 42 U.S.C. $\S 1396 \mathrm{a}(22)(B)(1988)$ ).

78. See supra note 22 and accompanying text. 
did promulgate regulations establishing minimal requirements for health care institutions, including nursing homes, participating in the Medicaid program. ${ }^{79}$ The nursing home requirements were generally less strict than Medicare standards. By regulation, HHS subsequently made Medicare Conditions of Participation for hospitals, nursing homes, and home health agencies applicable to institutions participating in the Medicaid program. ${ }^{80}$

Further, in the 1970s and 1980s, states increased their reliance on JCAHO accreditation as indicia that institutions met state licensure requirements. ${ }^{81}$ As of 1982, at least thirty-eight states had incorporated JCAHO accreditation into their facility licensure program in some capacity. ${ }^{82}$ Thus, although operationally different than the Medicare program, JCAHO accreditation has effectively performed a compliance determination for hospitals and, to a lesser extent, other health care institutions under most state Medicaid programs.

\section{Home Health Agencies}

Home health agencies had a different experience with private accreditation under the Medicare program than hospitals. As there has always been pluralism in private accreditation of home health agencies, ${ }^{83}$ it is not surprising that two major accrediting bodies, the National League of Nursing and the JCAHO, sought recognition as accreditors for the Medicare program. In the mid-1980s, the Health Care Financing Administration ("HCFA") agreed to "deem" accreditation by both the National League of Nursing and the JCAHO as compliance with Medicare standards. ${ }^{84}$ HCFA deferred recognition because Congress mandated changes in the Medicare Conditions of Participation for home health agencies as well as the survey and certification procedures for home health agencies. ${ }^{85}$ In 1991, HCFA proposed revisions in the Medicare Conditions of Participation for home health agencies. ${ }^{86}$

In 1991, HCFA again proposed recognition of the National League of Nursing and JCAHO accreditation. ${ }^{87}$ In May 1992, HCFA issued a notice

79. Notice of Interim Policies and Requirements, Amount, Duration, and Scope of Medical Assistance, 33 Fed Reg. 16, 165 (Nov. 5, 1968); Notice of Interim Policies and Requirements, Standards for Payment for Skilled Nursing Home Care, 34 Fed. Reg. 9788 (June 24, 1969); see Butler, supra note 31 , at $1322,1332$.

80. 42 C.F.R. $\S 482.1$ (hospitals); id. $\S 483.1$ (long-term care facilities); see infra note 104 and accompanying text.

81. Jost, supra note 21 , at 858 .

82. Id. at $844-45,848$.

83. See supra notes $44-49$ and accompanying text.

84. Notice, Medicare and Medicaid Programs: Recognition of Joint Commission on Accreditation of Healthcare Organizations' Home Care Program Standards and the National League for Nursing's Standards for Home Health Agencies, 52 Fed. Reg. 49,510 (1987) (proposed Dec. 31, 1987).

85. Omnibus Budget Reconciliation Act of 1987, Pub. L. No. 100-203, $\$ \S 4021-4022,101$ Stat. 1330, $1330-67$ to $1330-71$ (codified as amended at 42 U.S.C. $\$ 1395 \times(j)(1988)$ ).

86. Medicare Program Conditions of Participation for Home Health Agencies, 56 Fed. Reg. 32,967 (1991) (proposed July 18, 1991).

87. Notice, Medicare and Medicaid Programs: Recognition of the Community Health Accreditation Program Standards for Home Care Organizations, 56 Fed. Reg. 43,929 (1991) (proposed Sept. 5, 1991); Notice, Medicare Program: Recognition of the Joint Commission on the Accreditation of Healthcare 
granting "deemed" status to home health agencies accredited under the Community Health Accreditation Program standards of the National League of Nursing. ${ }^{88}$ A year later, in June 1993, HCFA issued a final notice providing that JCAHO accredited home health agencies would be "deemed" to comply with the Medicare Conditions of Participation. ${ }^{89}$. Both notices provided that private accreditation would be pursuant to an unannounced survey and contained other provisions to enhance government oversight.

Concerns about quality assurance of home health service agencies emerged because home health agencies provide care in patient's homes over which there is little or no oversight of services actually being delivered. ${ }^{90}$ The final notices recognizing JCAHO accreditation explicitly outlined extensive "look behind" provisions authorizing HHS or state agencies to conduct additional inspections or validate JCAHO accreditation findings. ${ }^{91}$

\section{Nursing Homes}

Private accreditation for nursing homes has always been controversial. Congress had been concerned about the adequacy of state licensure for nursing homes since the inception of the Medicare and Medicaid programs and had admonished states to improve licensure programs. ${ }^{92}$ In the late $1960 \mathrm{~s}$, Congress began holding extensive hearings on the serious quality problems in nursing homes throughout the United States $^{93}$ and produced a multivolume report outlining the serious quality problems in nursing homes and the inability of states as well as $\mathrm{HEW}$ to assure quality effectively. ${ }^{94}$

Consequently, in the Social Security Amendments of 1972, Congress specifically took steps to address these problems ${ }^{95}$ by creating a new category of nursing facility, called "skilled nursing facilities," to provide skilled nursing care under both the Medicare and Medicaid programs. ${ }^{96}$ All skilled nursing

Organizations Standards for Home Care Organizations, 57 Fed. Reg. 4044 (1992) (proposed Feb. 3, 1992).

88. Final Notice, Medicare Program: Recognition of the Community Health Accreditation Program Standards for Home Care Organizations, 57 Fed. Reg. 22,773 (May 29, 1992).

89. Final Notice, Medicare and Medicaid Programs: Recognition of the Joint Commission on Accreditation of Healthcare Organizations Standards for Home Care Organizations, 58 Fed. Reg. 35,007 (June 30, 1993).

90. See, e.g., The Black Box of Home Care Quality: Hearings before the House Select Comm. on Aging, 99th Cong., 2d Sess. (1986); Johnson, supra note 38, at 929.

91. 58 Fed. Reg. at 35,008 (1993); 57 Fed. Reg. at 22,774-75 (1992).

92. S. REP. No. 404, 89th Cong., 1st Sess. 76 (1965), reprinted in 1965 U.S.C.C.A.N. 1943, 2016; see Butler, supra note 32, at 1322-23; see also Patricia Butler, Nursing Home Quality of Care Enforcement: Part I-Litigation by Private Parties, 14 CLEARINGHOUSE REV. 622 (1980)[hereinafter Butler, Part I]; Patricia Butler, Nursing Home Quality of Care Enforcement: Part II-State Agency Enforcement Remedies, 14 ClEARINGHOUSE REV. 665 (1980).

93. Trends in Long-Term Care: Hearings Before the Subcomm. on Long-Term Care of the Senate Special Comm. on Aging, 91st-94th Cong. (1969-1975); see Butler, supra note 31, at 1322-23.

94. See Butler, supra note 31 , at $1322-23$ \& n.32.

95. Butler, supra note 31, at 1326.

96. Social Security Amendments of 1972, Pub. L. No. 92-603, § 246, 86 Stat. 1329, 1424 (codified as amended at 42 U.S.C. $\$ 1395 \times(j)(1988)$ ); see Butler, supra note 31, at 1322-23; see also Butler, Part 
facilities, whether participating in Medicare or Medicaid, were subject to the same conditions of participation and the same federally funded state survey and certification program." States continued to regulate "intermediate care facilities" that provided custodial nursing home care to Medicaid beneficiaries ${ }^{98}$

Nursing homes have for years pressed for the availability of the "deeming" mechanism of private accreditation for purposes of Medicare participation. In the early 1980s, the Reagan Administration proposed "deeming" JCAHO accreditation of nursing homes as compliance with Medicare conditions of participation requirements. ${ }^{99}$ This proposed rule precipitated a firestorm of consumer protest as well as congressional legislation establishing a six-month moratorium on use of private accreditation in the regulation of nursing homes ${ }^{100}$ and a call for a study of nursing home quality and enforcement by the Institute of Medicine. ${ }^{101}$ The Reagan Administration abandoned this initiative in the face of congressional pressure and a widely held belief that quality of nursing home care was problematic, governmental regulation of nursing homes was poor, and deregulation was thus unwarranted. ${ }^{102}$

Indeed, there was widespread concern about the quality of care in nursing homes. ${ }^{103}$ Following the publication of the Institute of Medicine report, Congress enacted detailed provisions on how states should regulate the quality of care in nursing homes through more rigorous procedures for the survey and certification of nursing homes by state agencies. ${ }^{104}$ Congress eliminated the distinction between "skilled nursing facilities" and "intermediate care facilities" 105 and consolidated regulation of all nursing homes providing services to Medicare and Medicaid beneficiaries into one program. The reforms in the Omnibus Budget Reconciliation Act of 1987 were consistent with the trends in

I, supra note 92 , at 622 .

97. See supra notes 4-9.

98. See supra note 76 and accompanying text.

99. Medicare and Medicaid Programs, Survey and Certification of Health Care Facilities, 47 Fed.

Reg. 23,407 (1982) (proposed May 27, 1982).

100. Tax Equity and Fiscal Responsibility Act of 1982, Pub. L. No. 97-248, § 135, 96 Stat. 324, 375.

101. COMmitTEE ON NURSING HoMe REG., InST. OF MEdicine, IMPROVING THE QUALITY OF CARE IN NURSING HOMES (1986).

102. Id. at 2; SUBCOMM. ON HEALTH AND THE ENVIRONMENT OF THE HOUSE COMM. ON ENERGY AND CoMmerce, 100TH CONG., 1ST SEss., Medicare AND MEdicaid Health BudGeT RECONCIliATION AMENDMENTS OF 1987, at 76-77 (Comm. Print. 1987); REPORT to THE RANKING

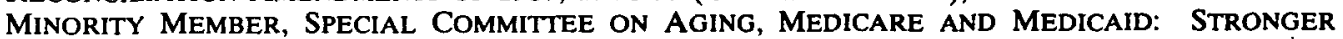
ENFORCEMENT OF NURSING HOME REQUIREMENTS NEEDED, H.R. DoC. No. 113, 87th Cong., 1st Sess. (1987).

103. See, e.g., UnITEd States General Accounting Office, Medicare and Medicaid: STRONGER ENFORCEMENT OF NURSING HOME REQUIREMENTS (July 1987); Henty A. Waxman, Consensus Calls for Nursing Home Reform, 12 PROVIDER, Nov. 1986, at 15.

104. Omnibus Budget Reconciliation Act of 1987, Pub. L. No. 100-203, \& 4211, 101 Stat. 1330, 1330188 to $1330-193$ (codified as amended in scattered subsections of 42 U.S.C. $\$ 1396$ (1988 \& Supp. V 1993)). Now, nursing homes participating in Medicaid must also meet Medicare Conditions of Participation. 42 C.F.R. $\$ \S 440.1-457$ (1993); see supra note 80.

105. Omnibus Budget Reconciliation Act of 1987, Pub. L. No 100-203, \& 4211, 101 Stat. 1330, 1330103 (codified as amended at 42 U.S.C. $\$ 1919$ (a) (1988)). 
nursing home regulation: increasingly rigorous and detailed government regulation with stricter federal oversight. It is noteworthy that commentators have suggested that the "deeming" mechanism, in lieu of direct government regulation, is inappropriate for nursing homes. ${ }^{106}$

\section{E. Continuing Controversy}

From the early days of Medicare and Medicaid, the role of JCAHO accreditation in determining compliance with Medicare conditions of participation has been controversial. Right off the bat, consumer groups challenged this JCAHO function for hospitals as an improper delegation of legislative power. ${ }^{107}$ In 1972 , Congress, responding to consumer pressure about the adequacy of JCAHO standards to protect consumers as well as the concerns about the propriety of the broad delegation, ${ }^{108}$ made the first of many changes in the "deeming" arrangement for JCAHO. Specifically, in the Social Security Amendments of 1972, Congress authorized HEW to promulgate hospital conditions of participation that were stricter than JCAHO standards. ${ }^{109}$ More importantly, Congress empowered HEW to validate JCAHO accreditation by state inspections performed at random or in response to complaints, and authorized the release of JCAHO accreditation survey reports to HEW for validation. $^{110}$ In the Deficit Reduction Act of 1984, Congress expanded the number of health care organizations for which "deeming" of private accreditation as compliance with Medicare conditions of participation was available. ${ }^{111}$ Congress also mandated that the Secretary of HHS keep accreditation surveys confidential. $^{112}$ Despite these changes, particularly in the expansion of HHS authority for direct oversight, the JCAHO "deeming" mechanism has remained the predominant method by which the Medicare program determines hospital compliance with Medicare Conditions of Participation. These reforms greatly enhanced federal oversight of the "deeming" process and ended the rather anomolous situation of the government regulator having no independent authority to verify the performance of the private accreditor.

In 1987, Congress made major changes in the procedures by which HCFA appoints accrediting bodies for which the "deeming" mechanism is available

106. Jost, supra note 21 , at 882 .

107. See Self-Help for the Elderly v. Richardson, No. 2016-71 (D.D.C. 1972); Jost, supra note 21, at 855.

108. Jost, supra note 21, at 855-57.

109. Social Security Amendments of 1972, Pub. L. No. 92-603, \& 244(b), 86 Stat. 1329, 1422-23 (codified as amended at 42 U.S.C. §§ 1395aa(c), 1395bb(a)(2) (1988 \& Supp. V 1993)); Jost, supra note 21 , at 856 \& n.186.

110. Social Security Amendments of 1972, Pub. L. No. 92-603, § 244(b), 86 .Stat. 1329, 1422-23 (codified as amended at 42 U.S.C. $\$ \S 1395 \mathrm{aa}(\mathrm{c}), 1395 \mathrm{bb}(\mathrm{a})(2)$ (1988 \& Supp. V 1993)); Jost, supra note 21, at 856 \& n.186.

111. Deficit Reduction Act of 1984, Pub. L. No. 98-369, $\S 2345,98$ Stat. 494, 1096 (codified as amended at 42 U.S.C. $\$ 1395$ bb (Supp. V 1993)).

112. Id. 
under section 1865 of the Social Security Act. ${ }^{113}$ Specifically, Congress required HCFA to publish a notice of its intent to recognize a private accrediting body in the Federal Register at least six months before it actually "deems" compliance with the accrediting body's standards as compliance with the Medicare Conditions of Participation. ${ }^{114}$ This requirement provides an opportunity for consumers and other interested parties to challenge HCFA decisions if they believe the standards or compliance determination procedures to be inadequate. In 1993, HCFA published a final rule setting forth procedures for recognizing the accreditation by private accrediting bodies as meeting the Medicare Conditions of Participation. ${ }^{115}$ These regulations implemented the important changes in the use of accreditation by Medicare that Congress adopted in the Deficit Reduction Act of 1984 and subsequent legislation. ${ }^{116}$

Confidentiality of accreditation reports has continued to be problematic. In the Medicare Catastrophic Coverage Act of 1988, Congress eliminated the confidentiality requirement for home health agencies altogether. ${ }^{117}$ In 1989, Congress authorized the Secretary of HHS to disclose an accreditation survey and associated information on all health care institutions to the extent the survey and information are related to an HHS enforcement action. ${ }^{118}$ Congress also mandated the release of information directly related to a JCAHO accreditation survey pertaining to whether an institution meets Medicare Conditions of Participation. ${ }^{119}$

Clearly the trend in the Medicare program is toward use of private accreditation to determine compliance with Medicare requirements for all healthcare institutions but with better oversight by HCFA. ${ }^{120}$ Hospitals and home health agencies now have the option of using the "deeming" mechanism. The option is theoretically available with nursing homes, although it does seem that this option is inconsistent with the tight regulation of nursing homes under the Omnibus Budget Reconciliation Act of 1987. ${ }^{121}$ Concomitant with the

113. 42 U.S.C. $\$ 1395 b b$ (1988 \& Supp. V 1993).

114. Omnibus Budget Reconciliation Act of 1987, Pub. L. No. 100-203, \& 4039(f), 101 Stat. 1330, 1330-82 (1987) (codified as amended at 42 U.S.C. \& 1395bb (1988 \& Supp. V 1993)).

115. Medicare: Granting and Withdrawal of Deeming Authority to National Accreditation Organizations, 58 Fed. Reg. 61,816 (1993) (to be codified at 42 C.F.R. pts. 401, 488, 489); see also Medicare: Granting and Withdrawal of Deeming Authority to National Accreditation Organizations, 55 Fed. Reg. 51,434 (1990) (proposed Dec. 14, 1990).

116. See supra note 112 and infra note 118.

117. Medicare Catastrophic Coverage Act of 1988, Pub. L. No. 100-360, \& 411, 102 Stat. 683, 768 (codified as amended at 42 U.S.C. \& 1395bb(a) (Supp. V 1993)).

118. Omnibus Budget Reconciliation Act of 1989, Pub. L. No. 101-239, \& 6019, 103 Stat. 2106, 21652166 (codified as amended at 42 U.S.C. $\$ 1395$ bb(a) (Supp. V 1993)).

119. $I d$.

120. See Douglas C. Michael, Federal Agency USe of Audited Self-Regulation as a REgUlATORY TECHNIQUE (1993) (Preliminary Draft for the Administrative Conference of the United States) (to be published in 47 ADMIN. L. REV., No. 2 (1995)).

121. See supra note 103 and accompanying text. Even HCFA has recognized the unlikelihood that private accreditors would be interested in developing programs for deeming nursing homes as meeting Medicare Conditions of Participation given the strict requirements of the Omnibus Budget Reconciliation Act of 1987. See Granting and Withdrawal of Deeming Authority to National 
expansion of the "deeming" option has been greater access to the information developed by private accreditors in the compliance determination process as well as increased regulatory controls such as access to and release of accreditation reports where private accreditation appears to have fallen short.

\section{IV}

\section{A TheORY for the APPRopriate USE of PRIVATE ACCREDItation}

In developing a theory for use of private accreditation in public health in public health insurance programs, an excellent point of departure is a recent recommendation of the Administrative Conference of the United States about the appropriate use of audited private regulation. ${ }^{122}$ Specifically, the Conference recommended that private regulatiom be used when both the responsible governmental agency and the private organization have the organizational ability in terms of expertise, experience and authority to implement the regulatory assignment effectively. ${ }^{123}$ Also, according to the Administrative Conference, the private organization should have fair procedures for the development of regulatory standards and the responsible governmental agency should have access to applicable records of the private organization. ${ }^{124}$

Initially, the use of private accreditation by the Medicare program for hospitals did not meet these criteria mainly because the JCAHO accreditation reports were confidential even from federal regulators. ${ }^{125}$ But as indicated above, Conhress has modified this situation substantially and has required private accreditors to provide HCFA with accreditation reports and even to publicize the reports to the extent they relate to governmental enforcement actions. ${ }^{126}$ Over time, Congress and HHS have become more thoughtful about the use of private accreditation so that the deeming arrangement comports, for the most part, with the criteria for appropriate use of private regulation the Administrative Conference recommends.

However, just meeting the Administrative Conference recommendations is not sufficient in public health insurance programs. A theory of appropriate use of private accreditation in public health insurance programs also requires consideration of the nature and types of institutions to be accredited.

\footnotetext{
Accreditation Organizations, 58 Fed. Reg. 61,816, 61,823 (1993).
}

122. Administrative Conference of the United States, The Use of Audited Self-Regulation as a Regulatory Technique, Recommendation 94-1 (adopted June 16, 1994), 59 Fed. Reg. 44,701 (Aug. 30, 1994); see MICHAEL, supra note 120.

123. Administrative Conference of the United States, The Use of Audited Self-Regulation as a Regulatory Technique, Recommendation 94-1 (adopted June 16, 1994), 59 Fed. Reg. 44,701 (Aug. 30, 1994); see MiCHAEL, supra note 120.

124. Administrative Conference of the United States, The Use of Audited Self-Regulation as a Regulatory Technique, Recommendation 94-1 (adopted June 16, 1994), 59 Fed. Reg. 44,701 (Aug. 30, 1994); see MICHAEL, supra note 120.

125. See supra note 73 and accompanying text.

126. See supra notes 107-21 and accompanying text. 
From the inception of the Medicare and Medicaid programs, the federal government and the states have treated hospitals, nursing homes, and home health agencies differently with respect to the role of private accreditation in defining and enforcing quality standards. Specifically, HHS permitted an expanded role of private accreditation for hospitals but has been reluctant to extend this role to other types of health care institutions, particularly those engaged in long-term care. Only recently has HHS permitted private accreditation of home health agencies to demonstrate compliance with the Medicare Conditions of Participation. ${ }^{127}$ Regarding nursing homes, the trend has been toward increasingly strict government regulation and until recently outright rejection of the use of private accreditation. ${ }^{128}$

This history suggests that important reasons may exist for the disparate treatment of these health care institutions in terms of private accreditation under the Medicare and Medicaid programs. Clearly, in terms of delegating to private accreditors the compliance determination function regarding quality standards, there has been consensus that hospitals, nursing homes, and home health agencies should be treated fundamentally differently. Yet, what differences between hospitals, nursing homes, and home health agencies warrant this belief? Now that Congress and HCFA have expanded Medicare's use of private accrediting bodies to all types of health care institutions, the disparate quality assurance experience with hospitals, home health agencies, and nursing homes may provide helpful insights for the future use of accreditation of the Medicare program and new health insurance programs established under any health reform initiative.

To answer the question of when private accreditation is appropriate, one must examine the characteristics of health care institutions and the patients they serve. ${ }^{129}$ With regard to the institutional characteristics, the important factors are the following: (1) the type of institutional control in terms of corporate status and professional involvement; (2) the accessibility to the public; and (3) the type of services offered. ${ }^{130}$ Regarding patient populations, important factors include the degree of dependency, vulnerability, and mental competence. Also important are the mechanisms for assuring accountability of private accreditors and public regulators in their compliance determination function and, specifically, whether significant differences exist between these mechanisms.

127. See supra notes $69-70$ and accompanying text.

128. See supra notes $98-105$ and accompanying text.

129. In developing this theory, I am indebted to Professor Sandra H. Johnson of the St. Louis University School of Law, whose work analyzed different regulatory approaches to quality assurance for hospitals and nursing homes and the implications for quality assurance for home health agencies. See Johnson, supra note 38, at 923-33.

130. Id. at 924 . 


\section{A. Characteristics of Providers, Their Services, and the Patients They Serve}

The following specific characteristics of providers are important in determining the appropriateness of private accreditation for public health insurance programs: the nature of institutional control; public accessibility to the venue where care is directly provided to the patient; and the type of services provided. Perhaps of most overriding concern are characteristics of the institution's typical patients and, specifically, the degree to which they are dependent, vulnerable, and of diminished mental capacity.

There are two aspects to the factor of institutional control. One is the traditional notion of corporate control, that is, for-profit or not-for-profit. The prevailing assumption regarding the health care industry is that not-for-profit organizations have a greater commitment to quality and a greater capability to assure quality than for-profit corporations. ${ }^{131}$ While this assumption may be overstated or even unfounded, ${ }^{132}$ the dominance of the for-profit corporate form in the nursing home industry has been noted as a leading reason for quality problems in that sector. ${ }^{133}$ Hospitals, which have enjoyed private regulation under Medicare since the program's inception, are distinguished by community prestige and a dominant not-for-profit tradition. ${ }^{134}$ Home health agencies are divided among not-for-profit visiting nurse associations with their heritage in the public health mission of the nineteenth century and a vigorous for-profit sector of more recent origin. ${ }^{135}$

The second and probably more important consideration is the nature of the professional control and, specifically, whether there is a single profession dominating the management of the institution. If there is a dominant professional group that has its own traditions of professional excellence and mechanisms for professional discipline, then the impetus for quality assurance within the institutions maintained by the profession already exists at a high level. For example, the medical profession has dominant authority over the quality assurance mechanisms in hospitals, and the nursing profession has dominant authority over the quality of care in home health agencies. ${ }^{136}$ It is fair to assume that the professional ethics that mandate quality of care in the practice of these two professions are incorporated into the management policies

131. See, e.g., Dan W. Brock \& Allen E. Buchanan, The Profit Motive in Medicine, 12 J. MED. \& PHIL. 1 (1987); Arnold S. Relman, The New Medical-Industrial Complex, 303 NEW ENG. J. MED. 963 (1980); Robert Veatch, Ethical Dilemmas of For-Profit Enterprise in Health Care, in THE NEw HEALTH CARE FOR PROFIT: DOCTORS AND HOSPITALS IN A COMPETITIVE ENVIRONMENT 125 (Bradford H. Gray ed., 1983).

132. Baruch A. Brody, Justice and Competitive Markets, 12 J. MED. \& PHIL. 37 (1987); Arnold S. Relman \& Uwe Reinhardt, An Exchange on For-Profit Health Care, in FOR-PROFIT ENTERPRISE IN Health CaRe 209 (Bradford H. Gray ed., 1986).

133. Nicholas Rango, Nursing-Home Care in the United States: Prevailing Conditions and Policy Implications, 307 NEW ENG. J. MED. 883, 887 (1982).

134. See supra notes $10-11$ and accompanying text.

135. See supra notes $17-18$ and accompanying text.

136. See Johnson, supra note 38 , at 925-27. 
of the institutions that they dominate. It is significant that the nursing home industry, which is largely for-profit, developed chiefly under the auspices of laymen and has never been dominated by a single professional group. ${ }^{137}$ It has also exhibited serious quality and even safety problems. ${ }^{138}$

Accessibility to the venue of care is also crucial in determining the appropriateness of private accreditation for public health insurance programs. The more accessible and public the venue of care, the more likely it is that caregivers will feel accountable for the care they provide and for the behavior they exhibit during the provision of care. Conversely, the more isolated the venue, the greater the potential for poor care and even possible abuse by individuals providing services. Simply, direct supervision and oversight are not present in more isolated venues. Hospitals are relatively public venues for the provision of health care, with many people around to witness the provision of care. Nursing homes are more isolated, and families, when they visit, are the only regular observers of care provided. Home health agencies provide care in the most private of venues, the patient's home.

Another crucial factor is the character of services provided. Health care institutions are often defined by the type of services they provide, for example, long-term or psychiatric care, although this situation may change in the new health care environment. The most important distinction for the three types of health care institutions in this analysis is between long-term care and medical care. Long-term care services differ from acute medical services provided in a hospital or even skilled nursing services provided by Medicare-certified home health agencies. Most long-term care services are specifically designed to assist individuals in conducting the activities of daily living, ${ }^{139}$ unlike medical care which seeks to ameliorate or eliminate the physical condition that necessitates assistance in conducting those activities. ${ }^{140}$

As a result of this difference in the purpose of long-term care compared to medical care, the nature of the services involved are fundamentally different. ${ }^{141}$ Most of the individuals who provide direct services are "unskilled" in the sense that they do not have or need special education or extensive training to provide the service competently. The professional component of long-term care services, in contrast to medical care, resides primarily with the managers of the individuals providing direct care, for example, case managers with training in social work or nursing. Nurses do provide many long-term care services and specifically skilled nursing services, but they have a less direct role

137. See supra notes $12-15$ and accompanying text.

138. See supra notes $16-17$ and accompanying text.

139. Rosalie A. Kane \& Robert L. Kane, long-Term Care: Principles, Programs and POLICIES 4-6 (1987).

140. Rosalie A. Kane \& Robert L. Kane, Long-Term Care: Variations on a Quality Assurance Theme, 25 INQUIRY 132, 133 (1988).

141. Specifically, long-term care services are defined as "health, personal care, and social services given over a sustained period to persons who have lost some capacity for self-care because of a chronic illness or condition." Id. 
with those in need of help with activities of daily living. The Kanes have made an important observation about quality assurance for long-term care services:

\begin{abstract}
Whereas critics might accuse acute care providers of insufficient appreciation of their limitations and a tendency to pursue the inefficacious, LTC ["long-term care"] as a field suffers from the opposite predilection. It is plagued by an overriding sense that the clientele are in inevitable decline, which contributes to generally low self-esteem and discouragement among LTC practitioners. If LTC recipients inevitably worsen, why bother charting their deterioration? Quality assurance efforts in LTC, therefore, must combat therapeutic nihilism while achieving a synthesis between the principles of quality assurance and the nature of LTC. Because of its poor self-image and lack of independent, self-directed professional standard setting, improvements in LTC will require a stronger external impetus than is the case for acute care. ${ }^{142}$
\end{abstract}

The characteristics of typical patients of health care institutions are crucial in determining the appropriateness of private accreditation. The important patient characteristics are the degree of dependence, vulnerability, and mental capacity. Specifically, is the patient capable of leaving the facility if treated badly? Does the patient have the mental competence to recognize poor care or abuse? Is the patient so dependent as to be afraid to challenge an abusive or poor quality caregiver? Nursing home patients are very dependent and vulnerable; few have any expectation of returning to the community. Home health agency and hospital patients vary widely but are probably less dependent and vulnerable than nursing home patients. The more vulnerable, dependent, and mentally compromised the patients are, the greater the danger that these patients might be endangered if regulatory oversight of the safety and quality of their care is limited.

\title{
B. The Compliance Determination Function: Ensuring Accountability
}

A major concern regarding delegation of the compliance determination function is whether the private model imposes sufficient accountability on private accrediting bodies to ensure that they discharge their compliance determination function in ways that protect patients and treat providers fairly. With direct government regulation, accountability is presumably imposed through the political process. Specifically, regulators in a democratic system are subject to pressure from elected officials if their performance is deficient. Further, public regulators are generally subject to extensive legislative, executive, and judicial oversight, unlike private accreditors. ${ }^{143}$

The question then is whether comparable accountability can be achieved when private accrediting bodies conduct the compliance determination function. ${ }^{144}$ However, one must not assume that government necessarily acts with more accountability than private accreditors. Rather, one must analyze the detailed characteristics of genuine accountability to determine if these features

142. Id. at 132; see also Johnson, supra note 38, at 924.

143. Kane \& Kane, supra note 140 , at 132.

144. See Abramson, supra note 4, at 182 . 
can be present or incorporated into a compliance determination function that relies chiefly on private accrediting bodies.

The best means for assuring accountability in the compliance determination function, for both patients and providers, would be to establish procedures that allow patients and providers to challenge decisions that they believe are inaccurate. However, neither the Medicare and Medicaid statutes nor state licensure laws contain provisions allowing either patients or providers to challenge the decisions of private accreditors. The Medicare statute does provide for government oversight of the decisions of private accreditors regarding accreditation of health care institutions. As discussed above, Congress has increased oversight over JCAHO accreditation of hospitals since the inception of the Medicare program. ${ }^{145}$ Also, with the "deeming" of private accreditation of home health agencies, HHS expressly required "look behind" authority for state agencies to check on accreditation decisions. ${ }^{146}$ Some state statutes and judicial decisions have recognized a private right of action to enforce state licensure laws particularly with respect to nursing homes. ${ }^{147}$ Finally, the JCAHO and other accrediting bodies do have procedures for providers to challenge accreditation decisions as well as extensive opportunities throughout the survey process to correct deficiencies and thereby remove the threat of losing accreditation.

The ability of private parties to challenge government decisions affecting them is a central concern of due process jurisprudence. The procedural due process doctrine ultimately seeks to impose accountability on public decisionmakers chiefly by requiring fair processes for making and renewing decisions rather than by assessing the substance of the decisions. Indeed, according to Mathews v. Eldridge, ${ }^{148}$ the essential inquiry in due process analysis is the nature of the interests of the private party and government and the degree to which additional procedures will positively influence the accuracy of the decision.

The threshold question in determining the rights of any challenger is whether the challenged activity involves public or private action. ${ }^{149}$ This issue

145. See supra notes $107-18$ and accompanying text.

146. See supra note 90 and accompanying text.

147. Clark C. Havighurst, Health Care law and Policy: Readings, Notes, and Questions 524-32 (1988); SANDRA H. JoHNSON ET AL., NURSING HOMES AND THE LAW: STATE REgulation AND PRIVATE LITIGATION \$§ 1-21 to 1-28, (1985); John P. Ludington, Annotation, Licensing and Regulation of Nursing or Rest Homes, 53 A.L.R.4TH 689 (1987 \& Supp. 1993); see also Estate of Smith v. Heckler, 747 F.2d 583 (10th Cir. 1984) (class action suit brought by nursing home residents receiving Medicaid holding that the Secretary of HHS had violated the Medicaid Act by failing to provide a system to inform herself adequately as to whether facilities receiving federal money were satisfying the Act's requirement for high quality patient care).

148. 424 U.S. 319 (1976).

149. See, e.g., Abramson, supra note 4; Henry J. Friendly, The Public-Private Penumbra-Fourteen Years Later, 130 U. PA. L. REv. 1289 (1982); Paul Brest, State Action and Liberal Theory: A Casenote on Flagg Brothers v. Brooks, 130 U. PA. L. REV. 1296 (1982); Frank I. Goodman, Professor Brest on State Action and Liberal Theory, and a Postscript to Professor Stone, 130 U. PA. L. REV. 1331 (1982); Morton J. Horwitz, The History of the Public/Private Distinction, 130 U. PA. L. REv. 1423 (1982). 
is important when government transfers functions to private organizations. In the case of private accreditation, does the Due Process Clause protect patients served by the accredited health care institution to challenge accreditation decisions which adversely affect their health and safety? Given that the decisions of private accreditors in these disputes pertain directly to certification for participation in government-sponsored health insurance programs, the determination of whether state action exists should be straightforward, unlike the determination in other contexts. ${ }^{150}$ In Schweiker v. McClure, ${ }^{151}$ the Supreme Court assumed that private actors executing Medicare program responsibilities, that is, private insurance companies conducting beneficiary appeals, must comport with due process requirements.

Having determined that the requisite public action is involved, the second inquiry is to determine whether there is a protected property or liberty interest. ${ }^{152}$ The rights of patients to challenge decisions of accrediting organizations exercising their compliance determination function is problematic. While patients clearly have a recognized entitlement interest in government health insurance programs, ${ }^{133}$ they have no protected rights upon which to base a challenge to accreditation decisions of private accreditors or even decertification decisions of government regulators. ${ }^{154}$

In Cospito v. Heckler, ${ }^{155}$ involuntarily committed patients in a psychiatric hospital for which the JCAHO terminated accreditation argued unsuccessfully that termination of their Medicare hospital benefits without allowing their participation in the JCAHO accreditation proceeding denied them procedural due process. The United States Court of Appeals for the Third Circuit ruled that there was no deprivation of a protected interest under procedural due process because the patients' loss of benefits in the Medicare program was only "indirectly" caused by the government's decision to decertify the hospital. ${ }^{156}$ In O'Bannon v. Town Court Nursing Center, ${ }^{157}$ the Supreme Court denied that patients in a nursing home had a similar due process interest in the state's decertification of the facility under the Medicaid program. ${ }^{158}$

150. See, e.g., Flagg Bros., Inc. v. Brooks, 436 U.S. 149 (1978); Sniadach v. Family Finance Corp., 395 U.S. 337 (1969); Burton v. Wilmington Parking Auth., 365 U.S. 715 (1961).

151. 456 U.S. 188 (1982).

152. See, e.g., Mathews v. Eldridge, 424 U.S. 319 (1976); Goss v. Lopez, 419 U.S. 565 (1975); Goldberg v. Kelly, 397 U.S. 254 (1970).

153. See, e.g., O'Bannon v. Town Court Nursing Ctr., 447 U.S. 773 (1980); Mathews, 424 U.S. at 319; Goldberg, 397 U.S. at 254.

154. See, e.g., O'Bannon, 447 U.S. at 773; Cospito v. Heckler, 742 F.2d 72 (3d Cir. 1984), cert. denied, 471 U.S. 1131 (1985).

155. 742 F.2d 72 (3d Cir. 1984), cert. denied, 471 U.S. 1131 (1985).

156. Id. at 82 .

157. 447 U.S. 773 (1980).

158. At least one commentator has suggested that vulnerable nursing home patients should have a protected interest in nursing home decertification decisions because of the traumatic impact of the decision, given that they would have to move to maintain their health insurance benefits. See Jane Beyer, The Need to Change Traditional Entitlement-Doctrine Analysis in Decertification of Nursing Homes, 59 N.C. L. REV. 943 (1981): 
The protected interests of providers from a constitutional perspective are even more limited despite the fact that decisions of private accreditors and their role in determining participation in government health insurance programs greatly affect the economic interests of health care providers. The Supreme Court and lower federal courts have refused to recognize that providers have a protected interest under the Due Process Clause to participate in the Medicare and Medicaid programs. ${ }^{159}$ Nevertheless, courts have recognized an obligation of the government not grounded in the Constitution to proceed according to due process principles. Specifically, some authority provides that challengers have remedies against the government when it has not followed proper procedures in the decisionmaking process as contemplated by Congress. ${ }^{160}$ This hazy doctrine basically concludes that government must conduct its functions in an orderly, predictable, and fair manner in relation to all parties, not just those with a constitutionally protected property or entitlement interest. ${ }^{161}$ However, this authority provides little comfort to providers so long as accreditation determinations and state certification decisions are made through fairly regular procedures.

In sum, neither patients nor providers have any real recourse against government agencies or private accrediting bodies to challenge compliance determination decisions on substantive grounds under the Due Process Clause or other legal authority. However, the fact that the current legal position of patients and providers is essentially the same vis-à-vis government regulators and private accreditors is important. Decisions about the propriety of private accreditors' assuming the compliance determination function need not be made on the basis that extant legal rights or procedural protections are compromised by the selection of one approach over the other. Rather, decisions can be based on other substantive factors, such as whether beneficiaries of the governmentsponsored health insurance program have adequate input in the standards established or the enforcement procedures of any private accrediting body.

Currently, the political process is the avenue through which patients and providers impose accountability on either government regulators or private accreditors in the compliance determination function. Are private accreditors as sensitive to legitimate public pressure as government regulators in the compliance determination process? Empirical evidence is not available to answer this question definitively. A recently published study by Public Citizen's Health Research Group suggested some evidence that the JCAHO and its

159. See, e.g., O'Bannon, 447 U.S. at 773; St. Francis Hosp. Ctr. v. Heckler, 714 F.2d. 872 (7th Cir. 1983), cert. denied, 465 U.S. 1022 (1984); Geriatrics, Inc. v. Harris, 640 F.2d. 262 (10th Cir.), cert. denied, 454 U.S. 832 (1981).

160. See, e.g., Gonzales v. Freeman, 334 F.2d 570 (D.C. Cir. 1964).

161. Greene v. McElroy, 360 U.S. 670 (1959); Scanwell Lab., Inc. v. Shaffer, 424 F.2d 859 (D.C. Cir. 1970); Gonzales, 334 F.2d at 570; Garrott v. United States, 340 F.2d 615 (Ct. Cl. 1965). See generally Kenneth Culp Davis, Administrative LAW TeXT $\$ 7.13$ (3d ed. 1972). 
compliance determination procedures exhibited shortcomings with respect to accountability. ${ }^{162}$

There are incentives in the current private accreditation process that do suggest that the political pressures on private accreditors would be different. Specifically, health care institutions pay for the accreditation process and private accreditors depend on those fees for their financial well-being. Also, private accreditors are dominated by the institutions and professions that they regulate in ways that government regulators are not. These factors suggest that direct government regulation may be more susceptible to legitimate political pressure, particularly from consumers, and it may be more sensitive in assuring the protection of vulnerable and dependent patients in the public quality assurance process.

C. The Standard Setting Function: Ensuring Pluralism, Progress, and Consumer Choice

The theory presented above for assessing when and how private accreditation should substitute for direct government regulation in public health insurance programs pertains chiefly to the delegation of the compliance determination function. However, there are important issues regarding the delegation of the standard setting function as well.

Under the predominant model for use of private accreditors in government health insurance programs, such as the Medicare program, the standards of private accreditors can serve only as the basis of the Medicare program's quality definition and assurance function if they track the Medicare Conditions of Participation. ${ }^{163}$ For example, as discussed above, HCFA deferred recognition of two private accreditors for home health agencies after Congress changed the conditions of participation for home health agencies, because the standards of the private accreditors needed revision to comport with the revised federal standards. ${ }^{164}$ Thus, even though the Medicare statute ostensibly encourages the use of private accreditation to define quality, the pressure on private accreditors to be recognized by the Medicare program results in a convergence of the standards of private accreditors with the Medicare Conditions of Participation.

This phenomenon is unfortunate. According accrediting bodies the imprimatur of government approval when their standards conform to government standards for government health insurance programs has a potentially undesirable impact on the development of new quality standards and measures. It is significant that the JCAHO, the predominant accreditor for health care institutions, has really not been the leader in developing quality standards for

162. Joan Steiber \& Sidney M. Wolfe, Public Citizen's Health Research Group, Who's WATCHING OUR HOSPITALS? 30 (1994).

163. 42 U.S.C. $\$ 1395$ bb (1988 \& Supp. V 1993).

164. See supra note 84 and accompanying text. 
any health care institution. Indeed, the two major quality assurance movements of the last twenty years, the emphasis on outcomes as the definitive feature of quality $^{165}$ and the total quality management movement, ${ }^{166}$ developed first within health institutions and the health services research community. Only later, and then only in response to pressure from these constituencies, did JCAHO standards incorporate these innovative developments into quality assurance in the health care field. ${ }^{167}$ Now the JCAHO sees outcomes and other similar clinical indicators as crucial components of quality assurance that serve to meet the public accountability needs of health care institutions:

The Joint Commission, as the traditional standard-setter for quality of care, clearly has a potential role in helping physicians and health care organizations meet their public accountability needs. But the historical approach of establishing structure and function standards, which only determine a capability for providing high-quality patient care, will no longer suffice. There is now a need to determine whether that capability was effectively acted out. Indeed, did the patient benefit or perhaps suffer from the provision of services or the lack thereof? ${ }^{168}$

Private accreditors, independent of a regulatory role in government public health insurance programs, would have greater flexibility to conceptualize quality of care in innovative ways and possibly develop better quality standards for the health care institutions they accredit. In so doing, they would have great potential to promote pluralism, diversity, and competition among health care institutions and thus greater consumer choice in a changing health care environment. ${ }^{169}$ Clearly, information about quality provided by accreditation is an important public good that can have a crucial impact on the ability of health care institutions to compete more effectively by distinguishing themselves from other providers. ${ }^{170}$

165. Robert H. Brook \& Katherine N. Lohr, Monitoring Quality of Care in the Medicare Program, 258 JAMA 3138 (1987); Robert H. Brook \& Katherine N. Lohr, Efficacy, Effectiveness, Variations, and Quality: Boundary-crossing Research, 23 MEdICAL CARE 710 (1985); Paul M. Ellwood, Shattuck Lecture-Outcomes Management: A Technology of Patient Experience, 318 NEW ENG. J. MED. 1549 (1988); David Eddy \& John Billings, The Quality of Medical Evidence: Implications for Quality of Care, HeAlTH AffaIRs, Spring 1988, at 19; Arnold M. Epstein, The Outcomes Movement-Will It Get Us Where We Want to Go?, 323 NEW ENG. J. MED. 266 (1990).

166. See Donald M. Berwick, Continuous Improvement as an Ideal in Health Care, 320 New ENG. J. MED. 53 (1989); Glenn Laffel \& David Blumenthal, The Case of Using Industrial Quality Management Science in Health Care Organizations, 262 JAMA 2869 (1989); see also AGENCY FOR HEALTH CARE POLICY AND RESEARCH, U.S. DEPARTMENT OF HEALTH AND HUMAN SERVICES, SUMMARY REPORT: PUTTING RESEARCH TO WORK IN QUALITY IMPROVEMENT AND QUALITY ASSURANCE (1993).

167. See Dennis S. O'Leary, The Joint Commission Looks to the Future, 258 JAMA 951 (1987); Dennis S. O'Leary, Agenda for Change Fosters CQI Concepts, 2 JoINT COMMISSION PERSP. 3 (1992); Steven Schroeder, Outcome Assessment 70 Years Later: Are We Ready? 316 NEW ENG. J. MED. 160 (1987).

168. O'Leary, supra note 167.

169. See Clark C. Havighurst, Commentary: Accreditation Competition Needed, MODERN HEALTH CARE, Nov. 16, 1992, at 24.

170. See Clark C. Havighurst \& Nancy M. P. King, Private Credentialing of Health Care Personnel: An Antitrust Prospective (pt. 1), 9 AM. J. L. \& MED. 131; Id. (pt. 2), 9 AM. J.L. \& MED. 263 (1983); Philip C. Kissam, Government Policy Toward Medical Accreditation and Certification: The Antitrust Laws and Other Procompetitive Strategies, 1983 WIS. L. REV. 1 (1983). 
While it is unlikely that HCFA and state Medicaid agencies are willing to deal with multiple accreditors whose standards vary widely, it is tantalizing to speculate as to what might evolve in the changing health care environment if public health insurance programs were to establish minimal standards for health care institutions and release all private accreditors from any regulatory responsibilities in public health insurance programs. What kind of innovative and imaginative quality improvement methods could they conceive and promote in the absence of a regulatory role? On the other hand, their regulatory responsibilities may promote an associated rigor and practicality in their standards of compliance reviews that might not otherwise be present.

Another problem with government delegation of the standard setting function for public health insurance programs for private accrediting bodies is accountability, particularly to consumers. Generally, when the federal government sets important standards for public health insurance programs, it uses rulemaking procedures such as the notice-and-comment procedures under the Administrative Procedure Act, ${ }^{171}$ which provides notice to consumers of the proposed standards and an opportunity to comment. With private accreditors, the process for influencing the content of standards is less accessible. Private accreditors do not have comparable formal processes by which to contact consumers in a systematic fashion and to assure that all consumers have an opportunity to influence the content of the standards.

Furthermore, few legal remedies exist to enforce the accountability of private accreditors in their exercise of the standard setting function, particularly for consumers. Specifically, due process protections are really only available to parties challenging the compliance determination function of an accrediting body, an adjudicative activity, and not the standard setting function, a legislative activity. Generally, individuals have greater rights to protection under due process when government or its delegates are adjudicating rights and responsibilities under existing laws and policy than when government and its delegates are engaged in the legislative function of policymaking. The Supreme Court has been quite emphatic in its declaration that legislative decisions do not warrant the provision of an individual process for those who would challenge the decision. $^{172}$

\section{$\mathrm{V}$ \\ CONCLUSION}

This article offers a theory and some observations on how and when private accreditation should assume regulatory functions in public health insurance programs. The theory developed suggests that the characteristics of institutions and patients are crucial in determining appropriateness of delegating the

171. 5 U.S.C. $\$ 553$ (1988 \& Supp. IV 1992).

172. See, e.g., United States v. Florida E. Coast Ry. Co., 410 U.S. 224 (1973); Bi-Metallic Inv. Co. v. State Bd. of Equalization, 239 U.S. 441 (1915); see Abramson, supra note 4, at 200. 
compliance determination function to new types of health care institutions. Currently, neither private accreditation nor public regulation offer particularly effective mechanisms for consumers to utilize in imposing further accountability on the part of decisionmakers in determining an institution's compliance with the health insurance program's quality standards, or even in setting the standards. But one must question whether the imposition of a regulatory role on private accrediting bodies inhibits the most promising contributions of private accreditation in the changing health care environment-redefining quality of health care services in innovative ways yet to be contemplated. 